\title{
Exchange Rate Volatility and Foreign Direct Investment
}

\author{
Samuel Erasmus Alnaa ${ }^{1, *} \&$ Ferdinand Ahiakpor ${ }^{2}$ \\ ${ }^{1}$ Department of Accountancy, Bolgatanga Technical University, Bolgatanga, Ghana \\ ${ }^{2}$ School of Economics, Department of Data Science and Economic Policy, University of Cape \\ Coast, Ghana \\ *Corresponding author: Department of Accountancy, Bolgatanga Technical University, \\ Bolgatanga, Ghana. E-mail: sam.alnaa@gmail.com
}

Received: July 13, 2020 Accepted: August 7, 2020 Published: September 18, 2020

doi: 10.5296/rae.v12i3.17737 URL: https://doi.org/10.5296/rae.v12i3.17737

\begin{abstract}
The paper seeks to determine the effect of exchange rate volatility on foreign direct investment in Ghana from 1986 to 2017. The study adopted the Generalized Autoregressive Conditional Heteroskedasticity model to fit the data set from 1986-2017. The results indicate that, previous quarter information can influence current quarter volatility in Foreign Direct Investment. Real exchange rate, gross domestic product and treasure bill rate considered as external factors, are all found to be significant. This shows that, volatility from these factors can spillover to volatility in foreign direct investment. To ensure stable inflow of foreign direct investment, we recommend that policies should gear towards stability in the forex market and interest rate among others.
\end{abstract}

JEL: C32, F21, F31,

Keywords: Foreign Direct Investment, volatility, exchange rate, GARCH 


\section{Introduction}

The effect of Foreign Exchange Volatility (FEV) on Foreign Direct Investment (FDI) has been well documented in the extant literature. Empirical evidence of the relationship between foreign exchange rate volatility and foreign direct investment is necessary for formulating policies that will help improve economic growth. However, research evidence have indicated theoretical uncertainty and inconclusive results about the impact on investment. Hence, from an empirical point of view, the exact relationship between FEV and FDI is uncertain (Dhaka et al., 2010; Sharifi-Renani and Mirfatah, 2012). This uncertainty arises as the impact can either be positive or negative depending on the assumption about the adjustment cost, the degree of competition and risk- aversion (Hanusch et. al., 2018, Ullah. S et.al.,2012, Dixit and Pindyck, 1994, Caballero, 1991, Zeira, 1990). Also, studies in this area, in both developed and developing countries focus on industrial level. To the best of our knowledge, there has not being any known empirical studies of the effect of exchange rate volatility on investment.

A number of empirical studies have confirmed a positive relationship between FEV and FDI. For instance, using the ex-post facto research design, Obi (2017), investigated the impact of FEV on FDI in Nigeria from 1999-2016. An estimation of partial coefficient using OLS showed that FEV have a positive significant effect on foreign private investment in the Nigerian economy. Another study conducted by Boahen and Evans (2014) in Ghana using Vector Error Correction Model underscored the positive impact of FEV on FDI. The study advocated for the implementation of policies that will stabilize the exchange rate and the interest rate. In Kenya, Elly and Ojung'a (2015), used an annual secondary data from 1981-2010 to analyse the relationship between FEV and FDI. The study showed a positive relationship between the two variables and hence recommended a robust macroeconomic environment that will attract foreign investors to increase the flow of FDI.

On the other hand, quite a significant number of empirical evidence has shown a negative relationship between FEV and FDI. Using auto regressive distributed lag and multivariate error correction method on a secondary time series dataset over a period of 1980 to 2010, Elahi (2011) analyzed the impact of exchange rate volatility on FDI of the Pakistan economy. The finding the study showed that FEV has a negative impact on FDI in the short run, hence underscored the need for adjustment and liberalization programme in the short run for the Pakistan economy. Ahza (2015), analysed the effect of FEV on FDI in South Asian Association for Regional Cooperation (SAARC) countries using data from 1981 to 2013. The results from the Generalised Methods of Moments showed a negative relationship between FEV and FDI. Wang (2013), sought to investigate the relationship between FEV and FDI in Brazil, Russia, India and China (BRIC) using data spanning from 1994-2012. Using a method developed by Pesaran, Shin and Smith in 2001, the outcome of the study showed a negative long relationship between FEV and FDI in China, Russia and India even though no connection between the two variables were found in Brazil. To add to the above, Okwuchukwu, (2015), found a negative relationship between the two variables both in the short and long run when he investigated the impact of exchange rate volatility and stock market performance on the inflow of FDI in Nigerian economy by employing a time series data from 1980-2013. He recommended the adherence to sound exchange rate management, which has the tendency of 
increasing production at the domestic level.

Latief and Lefen (2018) and Campa and Goldberg (1993) studied the linkage between exchange rates, international trade and investment, emphasizing the role of producer exposure through export sales and inputs of production. Latief and Lefen used the Generalized Autoregressive Conditional Heteroscedasticity $(\mathrm{GARCH})(1,1)$ and Threshold-Generalized Autoregressive Conditional Heteroscedasticity (TGARCH) $(1,1)$ whiles Campa and Godberg used two estimates of exchange rate volatility that is (i) the ratio of the standard deviation to the mean of the exchange rate index over the previous twelve quarters (ii) the standard deviation of the first differences of the logarithm of the exchange rate over the twelve previous quarters. With the use of two-stage least squares (2SLS) regressions, Campa and Goldberg found that the influence of exchange rate and its volatility on investment in the United States were more obvious in the 1980s than in the 1970s. The dollar had significant segregated effects on industries in the 1980s. While the effects of the dollar on non-manufacturing industries was vague, its depreciations (appreciations), decreased (increased) investment in the non-durables manufacturing sector. Latief and Lefen (2018) have noted again that, exchange rate volatility has significant impact on both international trade and FDI and that, exchange rate volatility can potentially hurt international trade and FDI.

Maepa (2016); Jeanneret (2010); Zolghadr (2009); Campa and Goldberg, (1999) found a negative relationship between exchange rate volatility and investment.

Also, Nucci and Pozzolo (2001) investigated the relationship between exchange rate fluctuations and the investment decisions of a sample of Italian manufacturing firms. Using firm-level panel data with Generalized Method of Moments (GMM), the findings support the view that, exchange rate depreciation has a positive effect on investment through the revenue channel, and a negative effect through the cost channel. However, there is variation of the magnitude of these effects over time as the firm's external orientation changes, which is determined by the share of foreign sales over total sales and the reliance on imported input. In addition, the results from the study further revealed that, the effect of exchange rate fluctuations on investment is stronger for firms with low monopoly power, especially if such firms are facing a high degree of competition from imported goods into the domestic market. Even more so if such firms are small in size such that, the degree of substitutability between domestically produced and imported inputs influences the effect through the expenditure side.

Further, Harchaoui et al. (2005) studied 22 Canadian manufacturing industries using industrylevel data so as to examine the relationship between real exchange rate and investment during the period 1981-1997. The results revealed statistical significance of the overall effect of exchange rates on total investment, and that non-uniform investment responses to exchange rate movements in three channels. The result corroborated earlier results in Campa and Goldberg (1999) which found that overall effect of the exchange rate on total investment was statistically insignificant for Canadian manufacturing sector between 1981 and 1997. On the flip side, they found that depreciations (appreciations) tend to have a positive (negative) impact on investment when the exchange rate volatility is relatively low. The results highlighted the importance of differentially investment response between a high and low exchange rate 
variability regime and that not only the level of the exchange rates but also the volatility matters for the firm's total investment decisions.

Ghana's economy has implemented various exchange regime from fixed to the market-oriented regime. However, for the past two decade, the country is implementing the Bretton Wood market determined exchange rate policies, since the introduction of this policy framework, the country's exchange rate continues to be highly volatile, with evidence from World Bank Development indicator data (2017).

Even though, Ghana has always experienced high level of exchange rate volatility, to the best of our knowledge, there is no known empirical studies on the effect of such volatility on foreign direct investment. Secondly, all known empirical studies in this area focus on industrial level. The study therefore, seeks to answer the following questions: i. Does exchange rate volatility affect volatility in foreign direct investment? ii. What other macroeconomic factors affect volatility in foreign direct investment in the Ghanaian economy? The study will also inform policy makers, especially monetary authorities, on factors to consider in policy formulation as far as foreign direct investment is concerned.

The rest of the study is organised as follows. Section two presents a description of the methodology and data for the study while section three presents the result and discussion of the results. The final section provides the conclusion and some policy recommendations.

\section{Methodology and Data}

\subsection{Econometric Model}

To answer the research questions stated in this study, volatility model was employed. Test for Autoregressive Conditional Heteroscedasticity $(\mathrm{ARCH})$ effect in the time series data for exchange rate and FDI was conducted. This was to determine if exchange rate in Ghana exhibited time-varying volatility clustering, i.e. periods of swings were followed by periods of relative calm.

ARCH model was first developed by Engle (1982) but was later generalized by Bollerslev (1986). ARCH means that the variance of a process (FDI in Ghana) changes in a systematic way over time.

In doing this, initial OLS regression was estimated to determine the impact of exchange rate volatility on foreign direct investment of the form:

$$
y_{t}=a_{0}+a_{1} x_{1 t}+\varepsilon_{t}
$$

Where; $\mathrm{y}_{\mathrm{t}}$ is foreign direct investment, $\mathrm{x}_{\mathrm{t}}$ is exchange rate while $\varepsilon_{\mathrm{t}}$ is the disturbance term. It is assumed that, conditional on the information available at time $(\mathrm{t}-1)$, the disturbance term is distributed as

$$
\varepsilon_{t} \square N\left[0,\left(\beta_{0}+\beta_{1} \varepsilon_{t-1}^{2}\right)\right] \text { or } \quad \varepsilon \sim \mathrm{D}\left(0, \mathrm{~h}_{\mathrm{t}}\right)
$$


That is, $\varepsilon_{t}$ is normally distributed with zero mean and

$$
\operatorname{Var}\left(\varepsilon_{t}\right)=\left(\beta_{0}+\beta_{1} \varepsilon_{t-1}^{2}\right)
$$

The variance equation can be restated as;

$$
h_{t}=\omega+\alpha_{1} \varepsilon_{t-1}^{2}
$$

The variance $\operatorname{var}\left(\varepsilon_{t}\right)\left[h_{t}\right]$, at any point in time, is said to be dependent on the squared disturbance at time (t-1). This gives the appearance of serial correlation. The error variance may depend not only on one lagged term of the squared error term but on several lagged squared terms as follows.

$$
h_{t}=\omega+\alpha_{1} \varepsilon_{t-1}^{2}+\alpha_{2} \varepsilon_{t-2}^{2}+\ldots+\alpha_{p} \varepsilon_{t-p}^{2}
$$

If there is no autocorrelation in the error variance, we have

$$
\mathrm{H}_{0:}=\alpha_{1}=\alpha_{2}=\ldots=\alpha_{p}=0
$$

In which case $h_{t}=\omega_{0}$, and we do not have the ARCH effect.

Due to the large persistence in volatility, the $\mathrm{ARCH}$ model often requires a large lagged length to fit the data. It is more parsimonious to use the Generalize ARCH (GARCH) model proposed by Bollerslev (1986). The conditional variance of a GARCH $(p, q)$ is therefore given as:

$$
h_{t}=\omega+\sum_{i=1}^{p} \alpha_{i} \mathcal{E}_{t-i}^{2}+\sum_{j=1}^{q} \beta_{j} h_{t-j}
$$

For the model to be well defined and the conditional variance positive, the parameters given the following constraints is specified as:

$$
\omega>0, \alpha_{i} \geq 0, \mathrm{i}=1, \ldots, \mathrm{p}, \beta_{j} \geq 0, \text { for } \mathrm{j}=1, \ldots, \mathrm{q}
$$

The variance of the error term is assumed to follow an ARMA (p,q)

\subsection{Estimated Model}

In this study, the $\operatorname{GARCH}(1,1)$ model mean and variance equations are given in equation $(1.1$ and 1.2) respectively:

$$
F D I=C_{1}+C_{2} I N F+e_{t}
$$

Where: $\quad F D I=$ foreign direct investment, $\mathrm{INF}=$ inflation, $\mathrm{C}_{1}=$ constant and $\mathrm{e}=$ residual term 


\section{Macrothink

To arrive at the variance equation, residual derived from the mean equation (1.1) is used in estimating the variance equation (1.2)

$H_{t}=C_{3}+C_{4} H_{t-1}+C_{5} e_{t-1}^{2}+C_{6} R E R+C_{7} G D P+C_{8} T B R$

where: $\mathrm{H}_{\mathrm{t}}=$ variance of residual (error term) derived from (1.1). It is also known as current or present day's variance or volatility in foreign direct investment $(\mathrm{FDI}), \mathrm{C}_{3}=$ constant, $\mathrm{H}_{\mathrm{t}-1}=$ previous quarter residual variance or volatility of FDI. It is also known as GARCH term., $e_{t-1}^{2}$ $=$ previous quarter squared residual derived from equation (1.1). It is also known as previous quarter FDI information about volatility; it is the ARCH effect, RER = real exchange rate, GDP $=$ Gross domestic product, $\mathrm{TBR}=$ Treasury Bill Rate (interest rate).

In this study, RER; GDP and TBR are exogenous or predetermined variables and are also known as variance regressors as they can also contribute in the volatility of FDI $\left(\mathrm{H}_{t}\right)$ in equation (1.2). This also means that, volatility in any of or all the exogenous variables (RER; GDP and TBR) can contribute to volatility in FDI. Equation $(1.2)$ is a $\operatorname{GARCH}(1,1)$ model as it has one $\operatorname{ARCH}\left(e_{t-1}^{2}\right)$ and one GARCH term $\left(\mathrm{H}_{\mathrm{t}-1}\right)$. In other words, it refers to first order ARCH term and first other GARCH term.

Thus, the aim is to model the volatility of FDI and exchange rate as well as other factors (volatilities) affecting volatility in FDI.

\section{Data}

The data used for the study are all sourced from the Bank of Ghana, World Development Indicator and Ghana Statistical Service from 1986 to 2017. The choice of this period is to critically examine the volatility in foreign direct investment as the economy continues to experience volatility in the exchange rate doing this period. The average exchange rate between the Ghana Cedi and the US dollar was used as a measure of exchange rate. Before proceeding with the estimation, the study dealt with a number of issues associated with data employed for the study. We first examined the time series properties of the series used. For example, the study used the Phillips-Perron unit root test and Augmented Dickey Fuller (ADF) test to check for stochastic trend in a time series, sometimes called a "random walk with drift". If the series has a unit root, it will show a systematic pattern that is unpredictable.

\section{Results and discussion}

In this section, the study presents the results from the estimated empirical GARCH model. The discussion of the results is also presented in this section. 


\subsection{Unit Root Test}

Table 1. Results of Phillips-Perron Unit Root Test of Series in Levels and First Difference

\begin{tabular}{llllcc}
\hline \multicolumn{2}{l}{ Unit root test in Levels } & & \multicolumn{3}{l}{ Unit root test in first difference } \\
\hline variable & Adj. t-stat & prob. Value & variable & Adj. t-stat & Prob. Value \\
\hline TBR & -2.058351 & 0.2620 & TBR & -5.134973 & 0.0000 \\
GDP & 3.622894 & 1.0000 & GDP & -4.970898 & 0.0000 \\
RER & -1.526623 & 0.5175 & RER & -4.687915 & 0.0001 \\
INFYON & -3.642880 & 0.8670 & INFYOY & -10.01136 & 0.0000 \\
FDI & -1.170459 & 0.6864 & FDI & -5.863267 & 0.0000 \\
\hline
\end{tabular}

Source: Estimated from Secondary dada, (1986-2017)

Table 1 shows the results from the unit root test conducted on the time series in the model. From the results we reject the null hypothesis that the series in levels are integrated or have unit root. However, after taking the first difference of the series, we reject the null hypothesis that, the series in first difference are integrated or not stationary. This therefore suggests that, the series are integrated of order one, in another word have unit root.

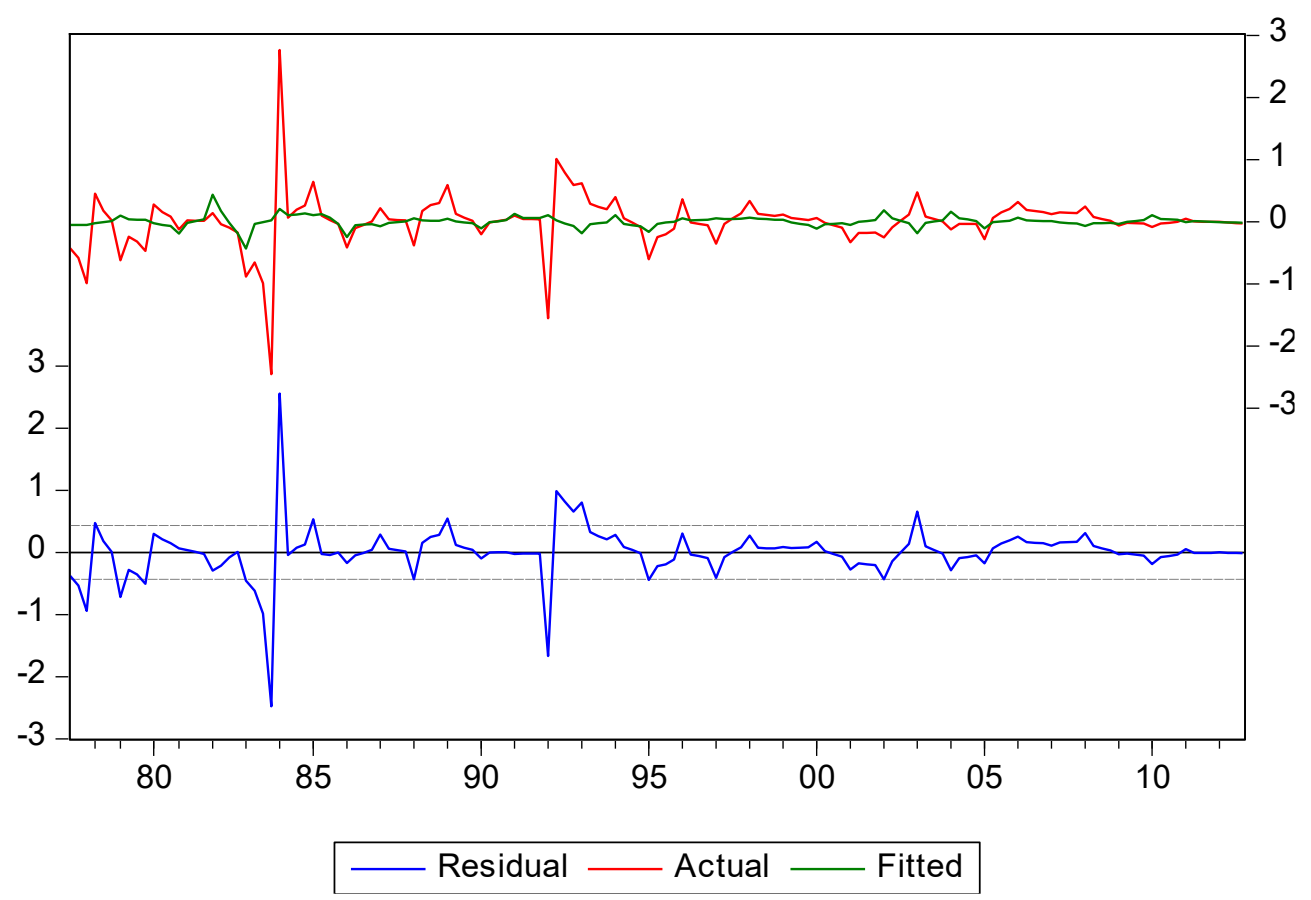

Figure 1. Residual Graph of FDI

Source: Constructed from secondary data, (1986-2017)

In addition, the residual graph from FDI as shown in Figure 1, indicates periods of relative volatility from 1975 to 1980 . This is followed by relative calm from 1980 to 1984 and again 
followed by high volatility from 1984 to 1985 . The trend continued with more prolonged periods of relative calm than periods of volatility. This therefore shows the presence of volatility clustering in FDI. This thus calls for fitting the data with a volatility model.

Table 2. Results of GARCH Model

\begin{tabular}{lllll}
\hline Variable & Coefficient & Std. Error & z-Statistic & Prob. \\
\hline C & 3.672997 & 0.468484 & 7.840177 & 0.0000 \\
INFYOY & 0.001959 & 0.000798 & 2.455852 & 0.0141 \\
& & & Variance equation \\
C & 0.003327 & 0.00021 & 15.26847 & 0.0000 \\
RESID(-1)^2 & 0.988854 & 0.109081 & 9.0653184 & 0.0000 \\
GARCH(-1) & -0.138308 & 0.052621 & -2.628380 & 0.0045 \\
RER & -0.040759 & 0.001324 & -30.78109 & 0.0000 \\
RGDP & -0.131810 & 0.022317 & -5.906298 & 0.0000 \\
TBR & -0.026399 & 0.003552 & -7.431461 & 0.0000 \\
\hline R-squared & -0.526906 & Mean dependent var & 2.167835 \\
Adjusted R-squared & -0.537153 & S.D. dependent var & 2.797037 \\
S.E. of regression & 3.467822 & Akaike info criterion & 2.854322 \\
Sum squared resid & 1791.842 & \multicolumn{2}{c}{ Schwarz criterion } & 3.014178 \\
Log likelihood & -207.5013 & Hannan-Quinn criter. & 2.919264 \\
Durbin-Watson stat & 0.015617 & & \\
\hline
\end{tabular}

Source: Estimated from Secondary dada, (1986-2017)

Table 2 shows the results of the GARCH model. The results indicate that, the residual term RESID (-1) ^2 is significant. This is the ARCH term, which suggests that, previous quarter information can influence current quarter volatility in foreign direct investment (FDI).

The GARCH $\left(\mathrm{H}_{\mathrm{t}-1}\right)$ is also significant at $5 \%$ and the coefficient is negative. This means that bad news about previous quarter volatility $\left(\mathrm{H}_{\mathrm{t}-1}\right.$ in equation 1.2) have more impact on current quarter volatility in FDI than good news of the same magnitude. This implies that, volatility in FDI is influenced by its own ARCH and GARCH or own shocks. Again, the sum of the coefficients of the ARCH and GARCH terms is close to unity $(0.988854+-0.138308$ $=0.850546$ ). This means that the internal or own shocks of FDI have a long memory process. It takes a long time before shocks to the variance (FDI) disappear.

Also, RER, RGDP and TBR are considered external factors, that is, factors not inherent in FDI. All these factors are significant. This means that, these external shocks can influence volatility in FDI. In other words, volatility in RER, RGDP and TBR can transmit or spillover to FDI. This is consistent with Xiong and Han (2015): Latief and Lefen (2018). 


\section{MlMacrothink}

\subsection{Residual Diagnostic Test}

We first checked for serial correlation in the model using the correlogram of the residual squared under the null hypothesis of no serial correlation.

\begin{tabular}{|c|c|c|c|c|c|}
\hline Autocorrelation & Partial Correlation & $A C$ & PAC & Q-Stat & Prob* \\
\hline 川 & 川 & $1-0.009$ & -0.009 & 0.0611 & 0.805 \\
\hline 1 & 1 & 20.000 & 0.000 & 0.0613 & 0.970 \\
\hline$\|$ & $\|$ & $\begin{array}{ll}3 & 0.022\end{array}$ & 0.022 & 0.4105 & 0.938 \\
\hline וهו & וקו & $4 \quad 0.030$ & 0.030 & 1.0415 & 0.903 \\
\hline 川 & $\|$ & $5-0.019$ & -0.018 & 1.2903 & 0.936 \\
\hline 1 & 1) & $\begin{array}{ll}6 & 0.083\end{array}$ & 0.083 & 6.2182 & 0.399 \\
\hline$\sqrt{1}$ & $\sqrt{1}$ & $7 \quad 0.003$ & 0.003 & 6.2248 & 0.514 \\
\hline il & il & $8-0.038$ & -0.038 & 7.2626 & 0.509 \\
\hline$\|$ & $\|$ & $9-0.019$ & -0.022 & 7.5237 & 0.583 \\
\hline 1) & 㠼 & $10 \quad 0.096$ & 0.091 & 14.109 & 0.168 \\
\hline ||li & 1" & $\begin{array}{ll}11 & 0.027\end{array}$ & 0.033 & 14.625 & 0.200 \\
\hline 1 & 1 & $12-0.001$ & -0.005 & 14.626 & 0.263 \\
\hline il & 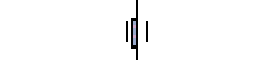 & $13-0.042$ & -0.048 & 15.899 & 0.255 \\
\hline$\|$ & $\|$ & 140.016 & 0.015 & 16.078 & 0.309 \\
\hline 1 & 1 & $15-0.054$ & -0.049 & 18.188 & 0.253 \\
\hline di & di & $16-0.089$ & -0.107 & 23.956 & 0.090 \\
\hline 11 & 11 & $17-0.001$ & -0.008 & 23.956 & 0.121 \\
\hline וp & וp & 180.028 & 0.038 & 24.526 & 0.139 \\
\hline d & 1 & $19-0.054$ & -0.034 & 26.665 & 0.113 \\
\hline וp & וp & $20 \quad 0.035$ & 0.027 & 27.567 & 0.120 \\
\hline 1 & 1 & $21-0.027$ & -0.031 & 28.093 & 0.138 \\
\hline ו & 1 & $22-0.015$ & 0.001 & 28.252 & 0.167 \\
\hline d & $d$ & $23-0.056$ & -0.051 & 30.551 & 0.134 \\
\hline וp & $\|$ & $24 \quad 0.027$ & 0.009 & 31.098 & 0.151 \\
\hline
\end{tabular}

Figure 2. Graph of Serial Correlation test

Source: Constructed from secondary data, (1986-2017)

From Figure 2, the results indicate that the p-values of the correlogram of the squared residuals are all above $5 \%$. We therefore accept the null hypothesis that there is no serial correlation in the model.

Secondly, we checked for ARCH effect in the model. We conduct the heteroscedasticity test under the null hypothesis of no ARCH effect. 
Table 3. Results of ARCH Test

Heteroskedasticity Test: ARCH

\begin{tabular}{|c|c|c|c|c|}
\hline F-statistic & 0.0445847 & \multicolumn{2}{|c|}{ Prob. $F(1,347)$} & 0.8330 \\
\hline Obs*R-squared & 0.044799 & \multicolumn{2}{|c|}{ Prob. Chi-Square(1) } & 0.8324 \\
\hline \multicolumn{5}{|l|}{ Test Equation: } \\
\hline \multicolumn{5}{|c|}{ Dependent Variable: RESID $^{\wedge} 2$} \\
\hline \multicolumn{5}{|c|}{ Method: Least Squares } \\
\hline \multicolumn{5}{|c|}{ Date: 04/26/19 Time: 08:36 } \\
\hline \multicolumn{5}{|c|}{ Sample (adjusted): 1986Q2 2017Q4 } \\
\hline \multicolumn{5}{|c|}{ Included observations: 151 after adjustments } \\
\hline Variable & Coefficient & Std. Error & t-Statistic & Prob. \\
\hline $\mathrm{C}$ & 1.013887 & 0.176479 & 5,745075 & 0.0000 \\
\hline $\operatorname{RESID}^{\wedge} 2(-1)$ & -0.011328 & 0.053673 & -0.211064 & 0.8330 \\
\hline R-squared & 0.870309 & \multicolumn{2}{|c|}{ Mean dependent var } & 4.451817 \\
\hline Adjusted R-squared & 0.869439 & \multicolumn{2}{|c|}{ S.D. dependent var } & 6.584637 \\
\hline S.E. of regression & 2.379246 & \multicolumn{2}{|c|}{ Akaike info criterion } & 4.584600 \\
\hline Sum squared resid & 843.4606 & \multicolumn{2}{|c|}{ Schwarz criterion } & 4.624564 \\
\hline Log likelihood & -344.1373 & \multicolumn{2}{|c|}{ Hannan-Quinn criter. } & 4.600836 \\
\hline F-statistic & 999.8847 & \multirow{2}{*}{\multicolumn{2}{|c|}{ Durbin-Watson stat }} & 0.589253 \\
\hline Prob(F-statistic) & 0.000000 & & & \\
\hline
\end{tabular}

Source: Estimation from Secondary dada, (1986-2017)

The results on Table 4 show that the p-value of the observed R-squared is 0.8324 . Thus, this is above $5 \%$ we therefore accept the null hypothesis that there is no ARCH effect in the model.

\section{Concluding Remarks}

The paper sought to determine if volatility in exchange rate and other macroeconomic factors affect volatility in Foreign Direct Investment (FDI). The study therefore, employed GARCH $(1,1)$ model using time series data from 1986-2017. A unit root test using Philip- Perron test shows all the series in levels are integrated of order one. That is, the series have unit root. The series were therefore differenced to make them stationary.

The results from the GARCH $(1,1)$ estimation show that, the ARCH term is significant at $1 \%$. The GARCH term was also significant with a P-value of 0.0045 . The study also concludes that, volatility in RER, RGDP and TBR can spillover to volatility in FDI in the Ghanaian economy.

We therefore recommend that, policy should be geared towards maintaining stability in the forex market in addition to stability in interest rate and the RGDP. This, if well implemented would have the effect of reducing if not eliminating volatility in FDI within the economy. 


\section{References}

Arellano, M., \& Bond, S. (1991). Some tests of specification for panel data: Monte Carlo evidence and an application to employment equations. The review of economic studies, 58(2), 277-297. https://doi.org/10.2307/2297968

Azhar, A., Ullah, N., \& Malik, Q. A. (2015). Effect of Exchange Rate Volatility on Foreign Direct Investment in Saarc Countries. Middle-East. Journal of Scientific Research, 23(2), 350-356

Bleaney, M., \& Greenaway, D. (2001). The impact of terms of trade and real exchange rate volatility on investment and growth in sub-Saharan Africa. Journal of development Economics, 65(2), 491-500. https://doi.org/10.1016/S0304-3878(01)00147-X

Boahen, E., \& Evans, O. (2014). The effect of exchange rate volatility on foreign direct investment in Ghana'. International Journal of Economic Behavior and Organization, 2, 20-28. https://doi.org/10.11648/j.ijebo.20140202.12

Bollerslev, T. (1986). Generalized autoregressive conditional heteroskedasticity. Journal of econometrics, 31(3), 307-327. https://doi.org/10.1016/0304-4076(86)90063-1

Caballero, R. J. (1991). On the sign of the investment-uncertainty relationship. The American Economic Review, 81(1), 279-288.

Campa, J. M., \& Goldberg, L. S. (1999). Investment, pass-through, and exchange rates: a crosscountry comparison. International Economic Review, 40(2), 287-314. https://doi.org/10.1111/1468-2354.00016

Campa, J., \& Goldberg, L. S. (1993). Investment in manufacturing, exchange rates and external exposure. Journal of International Economics, 38(3-4), 297-320. https://doi.org/10.3386/w4378

Dhakal, D., Nag, R., Pradhan, G., \& Upadhyaya, K. P. (2010). Exchange rate volatility and foreign direct investment: Evidence from East Asian countries. International Business and Economics Research Journal (IBER), 9(7). https://doi.org/10.19030/iber.v9i7.603

Dixit, A. K., Dixit, R. K., \& Pindyck, R. S. (1994). Investment under uncertainty. Princeton university press. https://doi.org/10.1515/9781400830176

Ellahi, N. (2011). 'Exchange rate volatility and foreign direct investment (FDI) behavior in Pakistan: A time series analysis with auto regressive distributed lag (ARDL) application'. African Journal of Business Management, 5(29), 11656. https://doi.org/10.5897/AJBM11.1676

Elly, O. D., \& Ojung'a, A. S. (2015). The Effect of exchange rate volatility on foreign direct investments in Kenyar from https://www.researchgate.net/publication/325082792

Engle, R. F. (1982). Autoregressive Conditional Heteroscedasticity with Estimates of the Variance of United Kingdom Inflation. Econometrica, 50(4), 987-1007. 
https://doi.org/10.2307/1912773

Hanusch. M., Ngugen. H., \& Algu. Y. (2018). Exchange Rate Vitality and FDI Inflows: Evidences from cross Country Panel Data. Discussion Paper, MTI Global Practice. https://doi.org/10.1596/29911

Harchaoui, T. M., Tarkhani, F., \& Yuen, T. (2005). The effects of the exchange rate on investment: Evidence from Canadian manufacturing industries (pp. 2005-22). Ottawa, ON: Bank of Canada.

Jeanneret, A. (2010). Foreign Direct Investment and Exchange Rate Volatility: a Non-Linear Story, Working Paper.

Latief. R., \& Lefen, L. (2018). The Effect of Exchange Rate Volatility on International Trade and Foreign Direct Investment (FDI) in Developing Countries along' "One Belt and One Road. International Journal of Financial Studies. Retrieved 9/8/2019 from file://C:/Users/P/Downloads/ijfs-06-00086\%20(1).pdf

Maepa, M. (2016). The effects of exchange rate volatility on South African investments. Economic Research Southern Africa, working paper 609

Martins, J. F. D. S. (2015). Impact of real exchange rate volatility on foreign direct investment inflows in Brazil (Doctoral dissertation)

Nucci, F., \& Pozzolo, A. F. (2001). Investment and the exchange rate: An analysis with firmlevel panel data. European Economic Review, 45(2), 259-283. https://doi.org/10.1016/S0014-2921(00)00050-7

Obi, C. (2017). The impact of foreign exchange volatility on foreign direct investment in Nigeria [1999-2016]. Global Journal of Management and Business Research

Okwuchukwu, O. (2015). Exchange rate volatility, stock market performance and foreign direct investment in Nigeria. International Journal of Academic Research in Accounting, $\begin{array}{llll}\text { Finance } \quad \text { and } \quad \text { Management } & \text { Sciences, }\end{array}$ https://doi.org/10.6007/IJARAFMS/v5-i2/1693

Serven, L. (1998). Macroeconomic uncertainty and private investment in LDCs: an empirical investigation (No. 2035). World Bank, Development Research Group, Macroeconomic and Growth. https://doi.org/10.1596/1813-9450-2035

Serven, L. (2002). Real exchange rate uncertainty and private investment in developing countries. The World Bank. https://doi.org/10.1596/1813-9450-2823

Sharifi-Renani, H., \& Mirfatah, M. (2012). The impact of exchange rate volatility on foreign direct investment in Iran. Procedia Economics and Finance, 1, 365-373. https://doi.org/10.1016/S2212-5671(12)00042-1

Ullah. S., Haider. S. Z., \& Azim. P (2012). Impact of Exchange Rate Volatility on Foreign Direct Investment: A Case Study of Pakistan. Pakistan Economic and Social Review, $50(2), 121-138$. 


\section{Macrothink}

Wang, D. (2013). The impact of exchange rate volatility on foreign direct investment (FDI) in BRIC countries. Retrieved from http://library2.smu.ca/bitstream/handle/01/25188/wang_danqing_mrp_2013.pdf?sequen ce $=1$ andisAllowed $=\mathrm{y}$

World Bank. (2012). The World Bank Annual Report 2012. The World Bank. https://doi.org/10.1596/978-0-8213-9568-4

Xiong, Z., \& Han, L. (2015). Volatility spillover effect between financial markets: evidence since the reform of the RMB exchange rate mechanism. Financial Innovation, 1(9), 1-12. https://doi.org/10.1186/s40854-015-0009-2

Zeira, J. (1990). Cost uncertainty and the rate of investment. Journal of Economic Dynamics and Control, 14(1), 53-63. https://doi.org/10.1016/0165-1889(90)90005-2

Zolghadr, M. (2009). Theoretical Basis of Foreign Direct Investment. Journal of Politics, Department of Law and Politics Magazine, 2, 89-107.

\section{Copyright Disclaimer}

Copyright for this article is retained by the author(s), with first publication rights granted to the journal.

This is an open-access article distributed under the terms and conditions of the Creative Commons Attribution license (http://creativecommons.org/licenses/by/3.0/). 